\title{
Characterization of eight species of Aloe (Asphodelaceae) from the nucleolar organizing region
}

\author{
Ysbelia Sánchez-G. ${ }^{1,2,6}$, María B. Raymúndez ${ }^{3}$, José Imery ${ }^{4}$, M. Cristina Acosta ${ }^{5}$ \& Eduardo Moscone
}

\begin{abstract}
Nucleolar organizing region of eight species of Aloe was analyzed in somatic metaphases and interphase nuclei. All species showed a uniform $2 \mathrm{n}=14$, with eight large chromosomes and six small chromosomes. Satellites were observed on the long arm of one or two pairs of large chromosomes and/or on the short arm of one of the small pairs. The silver-stained nucleolus organizing regions were located on the subtelomeric region of the long arm of one or two pairs of large chromosomes, except for Aloe dichotoma and Aloe maculata, which the AgNORs were located at a short arm of one of their small chromosomes. In most studied species, the active AgNOR number was four. However, this number changing from one to eight. For all species, the interphase number of nucleoli can be one or two, while, in Aloe excelsa, this number can be changing from one to eight. Polymorphism of active AgNORs and the number of interphase nucleoli were revealed, except for Aloe petricola, which active AgNORs were located only in the subtelomeric regions at the long arm of one of the $\mathrm{L}_{2}$ chromosomes, as well as in the $\mathrm{L}_{4}$ pair, which is agreement with the maximum number (three) of interphase nucleoli.
\end{abstract}

Key words: Aloe, AgNORs, nucleolar activity, silver-banding.

\section{Resumo}

A região organizadora nucléica de oito espécies de Aloe foi analisada em metáfases somáticas e núcleos interfásicos. Todas as espécies apresentaram um número uniforme de $2 n=14$, com oito cromossomos grandes e seis pequenos. Satélites foram observados no braço longo de um ou dois pares de cromossomos grandes e/ou no braço curto de um dos pares pequenos. As regiões organizadoras del nucléolo coradas com prata estavam localizadas na região subtelomérica do braço longo de um ou dois pares dos cromossomos grandes, exceto en Aloe dichotoma e Aloe maculata, em que os AgNORs estavan localizados em um braço curto de um de seus cromossomos pequenos. Na maioria das espécies estudadas, o número ativo de AgNOR era quatro. No entanto, esse número muda de um para oito. Para todas as espécies, o número de nucléolos na interfase pode ser um ou dois, enquanto, em Aloe excelsa, esse número pode estar mudando de um a oito. Polimorfismo de AgNORs ativos e o número de nucléolos em interfase foram revelados, exceto Aloe petricola, cujos AgNORs ativos estavam localizados apenas nas regiões subteloméricas no braço longo um dos cromossomos L2, bem como no par L4, concordando com o número máximo (três) de nucléolos em interfase. Palavras-chave: Aloe, AgNORs, atividade nucleolar, bandeamento de prata.

\section{Introduction}

The genus Aloe L. (Aloaceae Batsch), has about 581 accepted species (The Plant List 2013). Some species of Aloe (eg., Aloe vera, A. ferox, A. arborescens) have a economic importance worldwide due to high anthraquinones and pre-anthraquinones content, which have a medicinal applications. Also, this genus has ornamental applications, due to size and beauty in these plants (Reynolds 2004).

\footnotetext{
${ }^{1}$ Universidad Nacional Experimental del Táchira (UNET), Decanato de Investigación, Coord. Agropecuaria, Lab. de Investigaciones Genéticas, Sector 5001, Av. Universidad, San Cristóbal, Venezuela.

${ }^{2}$ Universidad Pedagógica Experimental Libertador (UPEL), Inst. Pedagógico de Caracas (IPC), Centro de Investigación en Ciencias Naturales (CICNAT), Lab. Botánica Sistemática, Av. Páez, AP 1020, Caracas, Venezuela.

${ }^{3}$ Universidad Central de Venezuela (UCV), Facultad de Ciencias, Inst. Biología Experimental (IBE), Lab. Biosistemática y Citogenética Vegetal, AP 47114, Colinas de Bello Monte, Caracas 1041-A, Caracas, Venezuela.

${ }^{4}$ Universidad de Oriente (UDO), Depto. Biología, Lab. Genética Vegetal, AP 245, Cumaná 6101, Venezuela.

${ }^{5}$ Universidad Nacional de Córdoba, Inst. Multidisciplinario de Biología Vegetal (IMBIV, CONICET), Lab. Citogenética, Av. Haya de la Torre s/n, Córdoba, Argentina.

${ }^{6}$ Author for correspondence: ysanchezg@unet.edu.ve
} 
Aloe is identify by the presence of succulent leaves, inflorescences in clusters or panicles, tubular flowers, the presence of secondary metabolic compounds as 1-methyl- 8-hydroxyanthraquinone in roots and C-glycosides in leaves. Additionally, Aloe have a basic chromosome number $\mathrm{x}=7$ (Reynolds 2004).

Most Aloe members are diploid $(2 n=2 x=14)$, however, some exceptions are tetraploid or hexaploid species, as A.tenuior and A. ciliaris, respectively (Brandham 1971). Both, Aloe and the other genera in this family, have a very stable basic bimodal karyotype with four large chromosomes $\left(\mathrm{L}_{1}-\mathrm{L}_{4}\right)$ and three small ones $\left(\mathrm{S}_{1}-\mathrm{S}_{3}\right)$, indicating a karyotypic orthoselection phenomenon (Brandham 1971; Brandham \& Doherty 1998). In classical cytogenetic studies in Aloe, secondary constrictions on the long arms of one or two pairs of large chromosomes and/or on the short arms of a pair of small chromosomes have been reported (Sharma \& Mallick 1965; Brandham 1971; Imery \& Caldera 2002), and scattered structural changes in chromosomes within populations of the same species were also detected (Brandham 1971; Vij et al. 1980). Such variations are not stable, within and between species, which has been attributed to the positive selection for maintaining a uniform karyotype (Brandham \& Doherty 1998).

Previous chromosome studies with banding techniques at $\mathrm{AgNOR}$ regions were limited to Aloe vera, reporting for the first time the location of active NORs in the short arms of chromosomes 1, 4, 6 and 7 without quantitative data (Matos et al. 1998). This location of active NORs does not match the secondary constrictions indicated in previous works (Brandham 1971; Imery \& Caldera 2002). Subsequently Imery (2007) reports the number and variation of AgNOR's stained nucleoli for $A$. vera and A. saponaria (= A. maculata). Moreover, Sánchez et al. (2007), had report a stable number of three AgNORs in A. petricola, corresponding with the maximum number of nucleolus in the studied interphase nucleus. Therefore, in this paper, we characterize the nucleolar organizing region of eight species of Aloe (A. immaculata Pillans, A.Berger, A. claviflora Burch., A. dichotoma Masson, $A$. excelsa A.Berger, $A$. grandidentata Salm-Dyck, $A$. littoralis Baker, A. maculata All. and A. petricola Pole-Evans) with AgNOR chromosome banding, in order to discuss their behavior and potential cytotaxonomic value in the group.

\section{Materials and Methods}

\section{Plant material}

Provenance of the plant material is presented in Table 1. Plants were grown under greenhouse conditions at the Department of Biology (Universidad de Oriente, Cumaná, Venezuela) and from germinated seeds at the Plant Biosystematics and Cytogenetic Laboratory (Universidad Central de Venezuela, Caracas).

\section{Cytological studies}

Root tips were pretreated with colchicine $(0,05 \% \mathrm{~m} / \mathrm{v}$ by $2 \mathrm{~h} 30 \mathrm{~min}$ at room temperature) and fixed in Farmer solution. Chromosome preparations were made by maceration in a pectinase - cellulase enzyme solution (Schwarzacher et al. 1980). Staining was done according to the Ag-I procedure described by Goodpasture \& Bloom (1975), Kodama et al. (1980) and Moscone et al. (1995), with appropriate modifications according to the standardization of each species and laboratory conditions (Sanchez et al. 2007). Number and location of active NORs and nucleoli in their corresponding interphase and metaphase, were studied, 20-50 metaphase plates and 15-88 interphase nuclei from each species were evaluated. Chromosomes were observed and photographed using a NIKON OPTIPHOT - 2 light microscope and a Leica light microscope equipped with a Leica DMLB DC 250 digital camera and Leica IM image analyzer 1000 .

Descriptions of the arrangement of chromosomes, were performed according to Levan et al. (1964) nomenclature and Brandham (1971). Chromosomes were organized into two groups according to their size, L and S (large and small, respectively), and within each category they were grouped according to the decreasing size of the short arm. Satellites were named according to the classification of Moscone et al. (1995), to the morphology of the worked chromosomes, being classified as microsatellites when the diameter is smaller than the diameter of the chromosome or arm carrying the secondary constriction, and/or macrosatellites when the diameter of the satellite match the diameter of the chromosome or the arm carrying it.

\section{Results and Discussion}

Karyotype formula, number and type of chromosomes carrying AgNORs at metaphase, NORs per haploid number and associated assets 


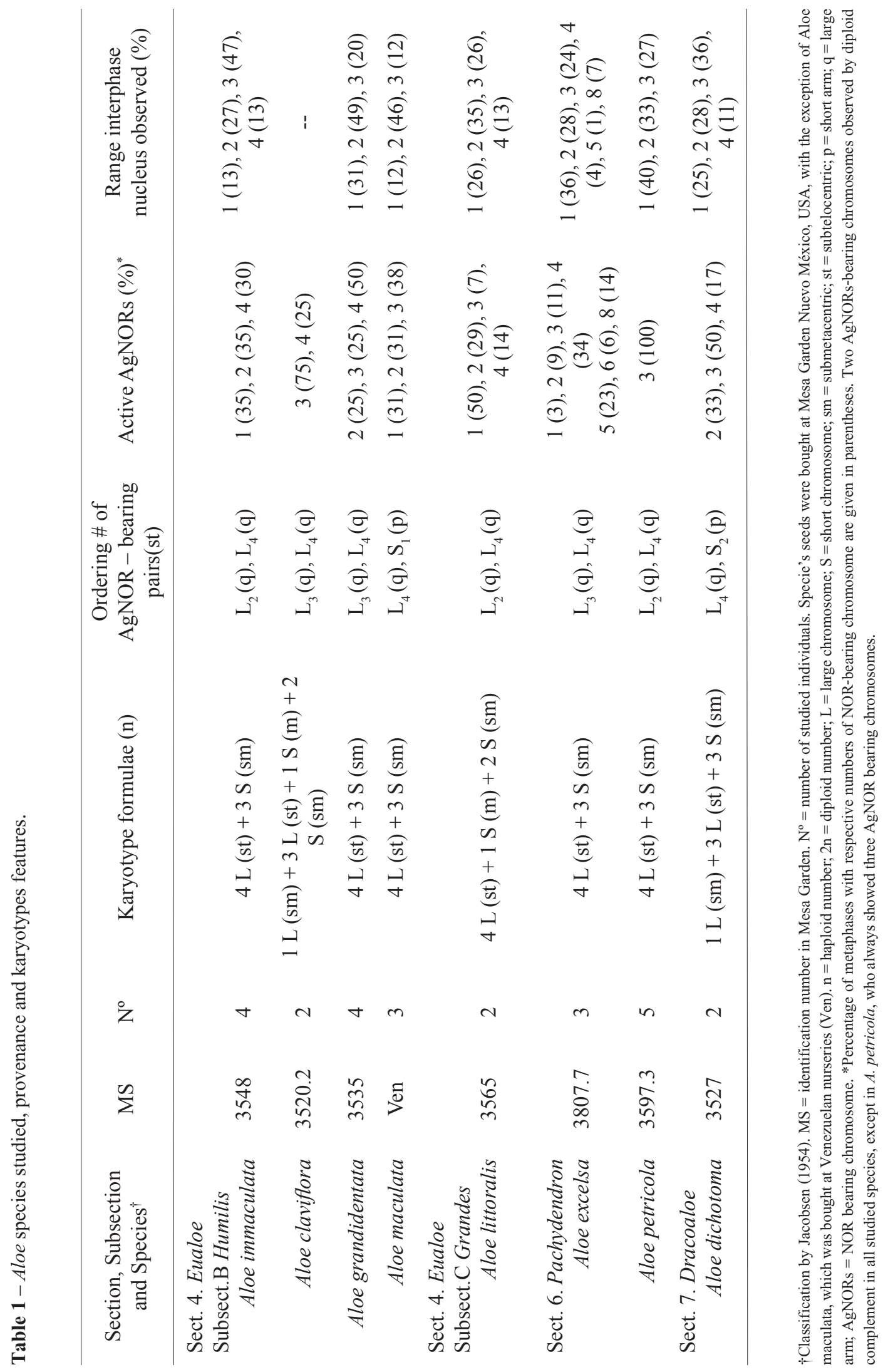


of diploid NORs, and number of nucleoli per interphase nucleus, organized for each taxa, are included in Table 1. Illustrations of the silver stained somatic metaphases and interphase nuclei are given in Figs. 1-3.

All species showed a uniform $2 n=14$ bimodal karyotype, with eight large chromosomes (pairs $\mathrm{L}_{1}, \mathrm{~L}_{2}, \mathrm{~L}_{3}$ and $\mathrm{L}_{4}$ ) and six small ones (pairs $\mathrm{S}_{1}, \mathrm{~S}_{2}$, $\mathrm{S}_{3}$ ). Satellites were observed in the long arm of one or two large (L) chromosome pairs and/or in the short arm of one pair of small (S) ones (Tab. 1). We found that satellites have constant size, and microsatellites are localized at the long arm of the large chromosomes where they are present (Figs. 1;2). The macrosatellites (when observed) are localized at the short arm of one of the small chromosomes, which showing the same size as the rest of the arm (Figs. 1e; 2a).

In almost all tested species, AgNOR bands were located on the long arm of one or two pairs of large chromosomes, except for Aloe dichotoma and $A$. maculata. In this species NORs were also revealed on one of the large chromosomes $\left(\mathrm{L}_{4}\right)$, as well as macrosatellites in the subtelomeric region of the short arm of one of the small chromosome pairs (Figs. 1; 2).

For most species, the number of AgNORs is four, but it can range from one (all species, except Aloe petricola) to eight (only in A. excelsa), being A. petricola, which exhibits a constant number of three active nucleolar organizer zones (Fig. 2c), which are agreement with other works (Sánchez et al. 2007).

The number of interphase nucleoli over the tested taxa is variable (Tab. 1, Fig. 3); it ranges from one and two (in all species), three (all, except in $A$. maculata), four (except in $A$. grandidentata and $A$. petricola) up to eight (only in Aloe excelsa).This nucleoli variation is agreement with the minimum and maximum number of estimated AgNORs per metaphase in the analyzed sample. The relative size of nucleoli varies within and between cells. Largest nucleoli were observed only in number of one or two per cell, as the product of the fusion of more than two initially free nucleoli (Fig. 3c,e), and small or medium ones were more numerous per cell, where the latest ones can be occasionally produced combining more than two small nucleoli per interphase nucleus (Fig. 3a,b,d).

The most species (Aloe immaculata, A. dichotoma, A. excelsa, A. grandidentata, A. littoralis, A. maculata and A. petricola) showed marked stained nucleoli. In A. claviflora's nucleoli could not be counted, because they did not stain with any silver method used. Finally, in $A$. petricola and $A$. excelsa, AgNOR's areas were observed more strongly marked than in the other species studied. This results show a significant intensity of neither active NOR stained bands.

\section{NOR's origin in Aloe}

The NORs located in the subtelomeric region of the long arm of $\mathrm{L}_{2}$ and $\mathrm{L}_{4}$ chromosome complements in Aloe immaculata, A. grandidentata, A. littoralis, A. petricola and A. excelsa; in $\mathrm{L}_{2}$ or $\mathrm{L}_{3}$ and $\mathrm{L}_{4}$ of $A$. claviflora, in $\mathrm{L}_{4}$ and the short arm of $\mathrm{S}_{1}$ in $A$. maculata, and in the long arm of $\mathrm{L}_{4}$ and the short arm of $\mathrm{S}_{2}$ in $A$. dichotoma are revealed at the same chromosome positions when revealed by CMA fluorescence chromosome banding as rich in CG-poor in AT bands (Sánchez 2010). This structural feature about NORs is common in plants (Berg \& Greilhuber 1992) and is shared by other groups as Crotalaria juncea L., Fabaceae (Modin et al. 2007), Cestrum parqui, Solanaceae (Berg \& Greilhuber 1992), and Prospero, Hyacinthaceae (Ebert et al. 1996), where NORs are also associated with $\mathrm{CMA}^{+}$bands.

Adams et al. (2000) indicate the location of the $5 \mathrm{~S}$ and $45 \mathrm{~S}$ ribosomal transcribed genes on the long arm of the large chromosomes and the short arm of a small chromosome in Aloe. NOR areas that are located on the large chromosome pair could correspond to $\mathrm{L}_{2}$ encoding $5 \mathrm{~S}$ rDNA localized with $45 \mathrm{~S}$ rDNA; this sequence remains conserved in species of Aloe evaluated by Adams et al. (2000), proving they could distinguish between $\mathrm{L}_{2}$ and $\mathrm{L}_{3}$, placed on $\mathrm{L}_{2}$, never in $\mathrm{L}_{1}, \mathrm{~L}_{3}$ or $\mathrm{L}_{4}$. On the other hand, Adams et al. (2000) identified NORs on $\mathrm{L}_{1}$ and $\mathrm{L}_{4}$ and on one of the small chromosome pairs $\left(\mathrm{S}_{1}-\mathrm{S}_{3}\right)$, like in A. maculata and A. dichotoma, could correspond to coding sequences for $45 \mathrm{~S}$ gene or the $18 \mathrm{~S}-5.8 \mathrm{~S}-26 \mathrm{~S}$ gene family. $45 \mathrm{~S}$ coding sequences from Lilium longiflorum and Lilium rubellum (Liliaceae) are generally associated with AgNOR+ secondary constrictions (Lim et al. 2001).

\section{NOR Polymorphism}

Nucleolar organizing sites were relatively constant between the evaluated species, and active NORs coincided frequently with the location of the secondary constrictions. Not all species exhibited secondary constrictions with active rDNA genes from the preceding interphase, for example, in Aloe immaculata, A. maculata and A. littoralis 


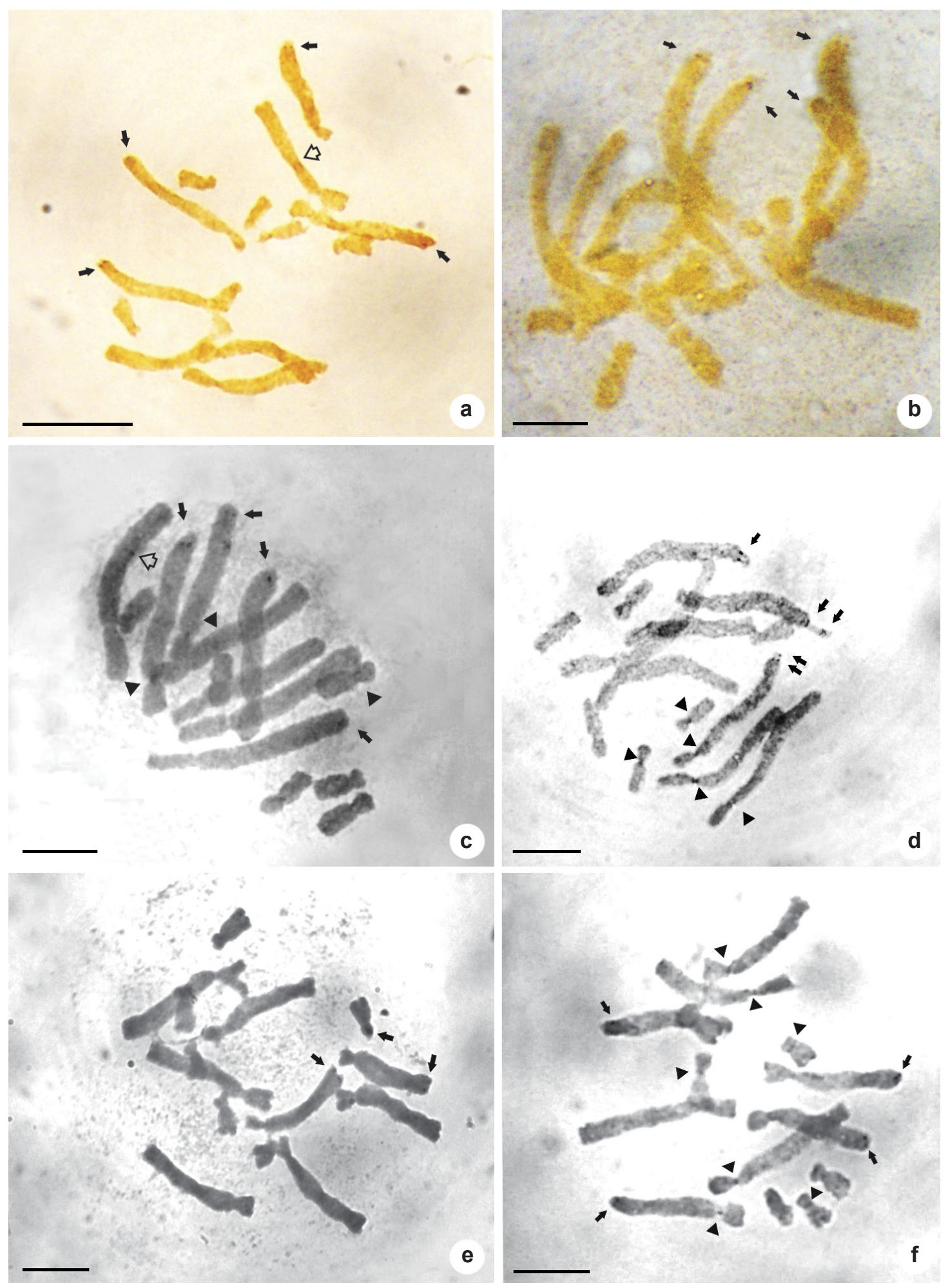

Figure 1 - Silver-stained somatic metaphases of Aloe: four AgNORs in (a) Aloe immaculata, (b) A. grandidentata and (c) A. claviflora; three AgNORs in (d) A. claviflora and two in tandem; three AgNORs in (e) A. maculata; four AgNORs in (f) A. littoralis. Black arrows indicate AgNOR's position black arrow heads indicate kinetocores white arrow heads indicate interstitial AgNORs in L1 chromosomes. Scale bars: $10 \mu \mathrm{m}$. 


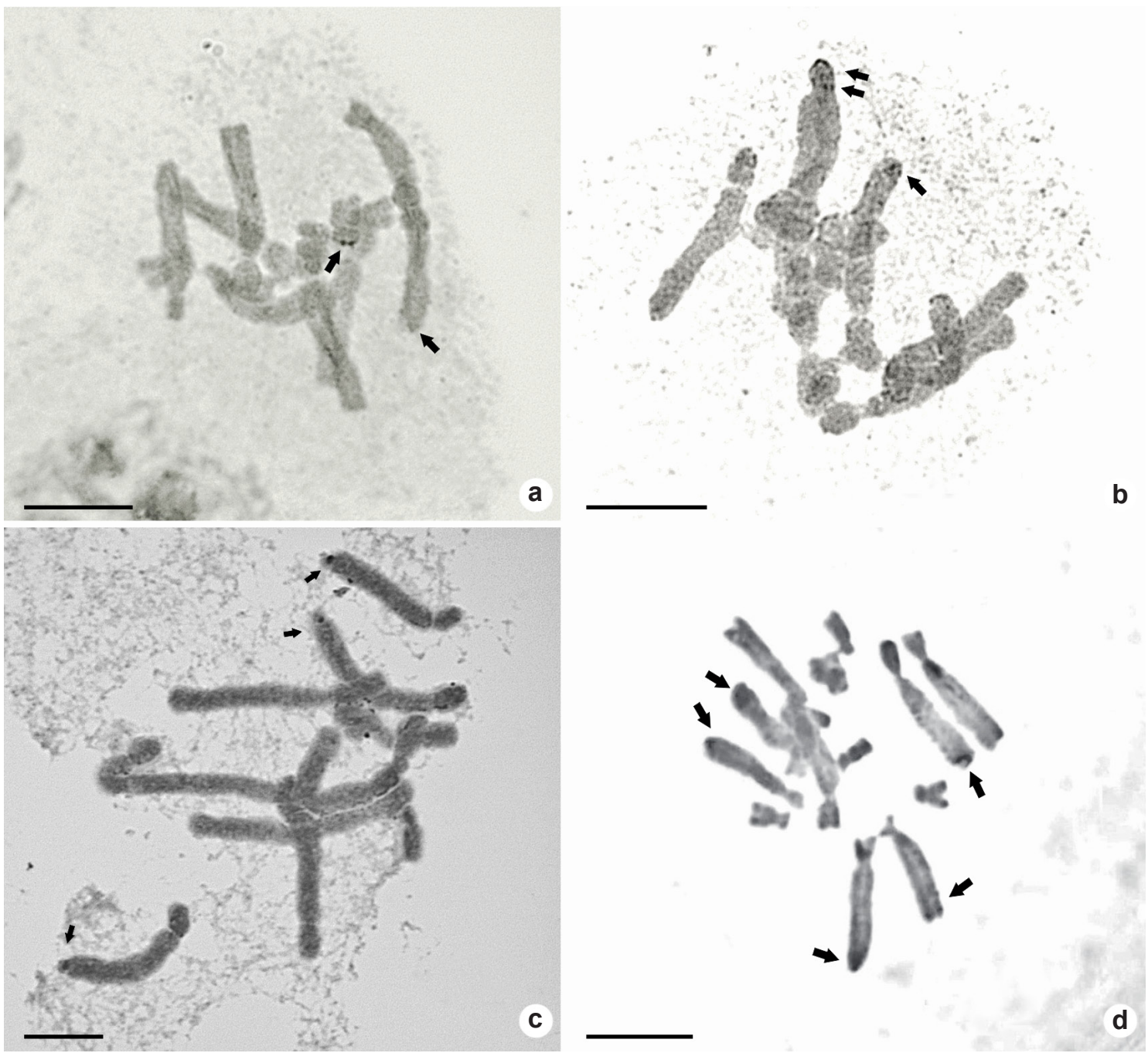

Figure 2 - Silver-stained somatic metaphases of Aloe: two AgNORs in (a-b) Aloe dichotoma; three AgNORs in (c) A. petricola; five AgNORs in (d) A. excelsa. Arrows indicate AgNOR's position. Scale bars: $10 \mu \mathrm{m}$.

where one active NOR area was observed in a high proportion of metaphases (Tab. 1) and not four, as expected according to the number of four secondary constrictions found. Apparently, the number of NORs in diploid plants varies between two and four, for example, there are two active NORs in Secale cereale, and two to four in Triticum aestivum and T. turgidum (Vieira et al. 1990), with these NORs being fewer active respect to the amount of observed secondary constrictions of the complete metaphase chromosome complement (Bourgourd \& Parker 1976; Vieira et al. 1990; Linares et al. 1992; Hasterok \& Maluszynska 2000).

Although the argentic banding can be used to detect stable polymorphisms in natural populations of Allium, and although the number of NORs may be related to a specific level of variation (Bourgourd \& Parker 1976), in the Aloe evaluated group, the number of active NORs is polymorphic for the studied species, finding one, two or four in Aloe immaculata, three or four in A. claviflora, from two to four in $A$. grandidentata, one to three in A. maculata, from one to four in A. littoralis, between one and eight in $A$. excelsa, and two to four in A. dichotoma. A only constant number was determined for $A$. petricola, displaying three active NOR areas in one of the complements of both $\mathrm{L}_{2}$ and $\mathrm{L}_{4}$ pairs (Tab. 1, Figs. 1; 2).

Similarly, the number of nucleoli in the interphase nuclei is also polymorphic, showing one to four in Aloe immaculata, A. littoralis and A. dichotoma, from one to three in A. claviflora, 


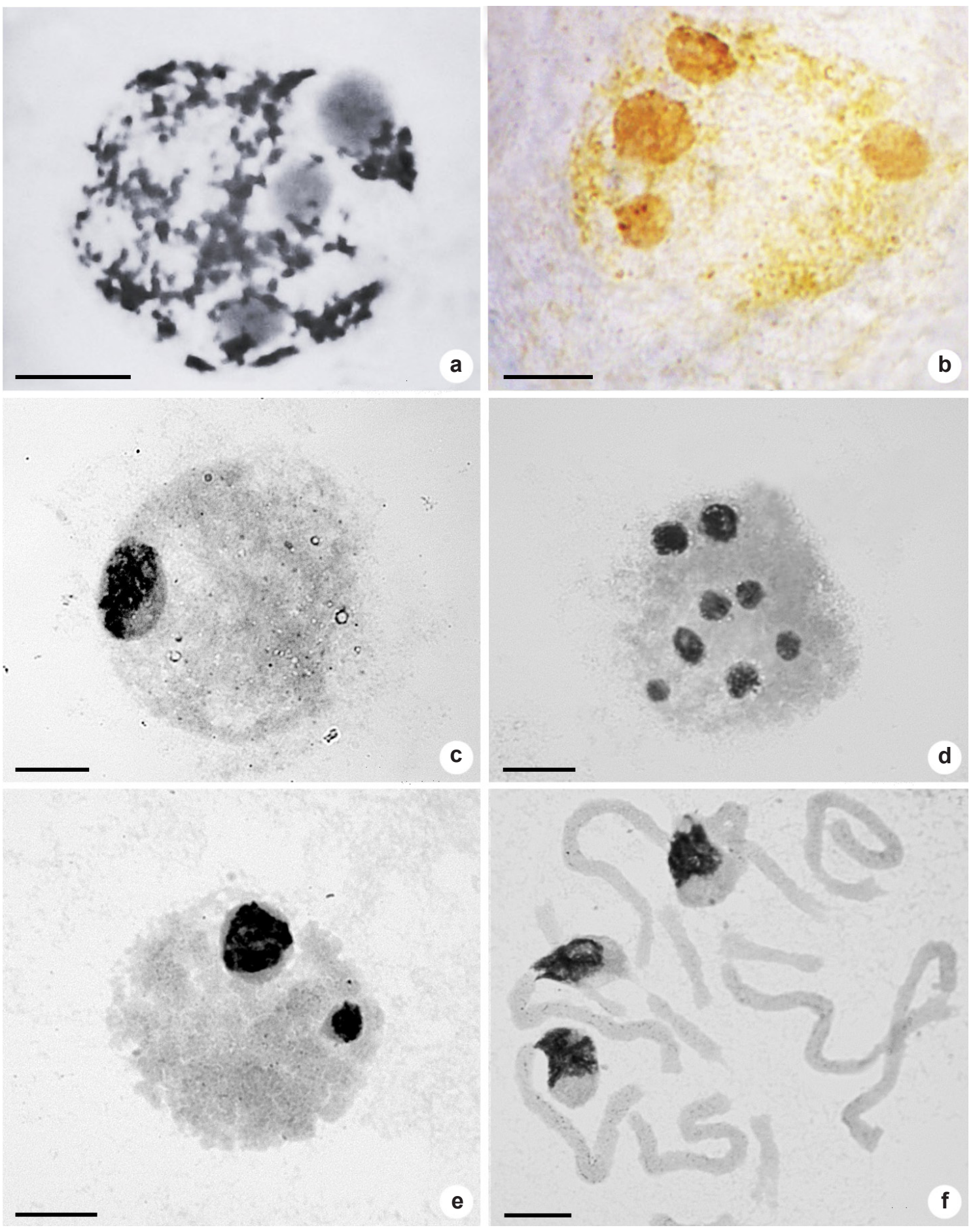

Figure 3 - Silver-stained interphase nuclei of Aloe: interphase nucleus with three Ag+ nucleoli in (a) Aloe immaculata; four Ag+ nucleoli in (b) A. dichotoma; one single big Ag+ nucleolus in (c) A. grandidentata; eight Ag+ nucleoli in (d) A. excelsa; two Ag+ nucleoli in (e) A. petricola, and nucleoli fusion can be observed prometaphase plate with three nucleoli, associated with three large chromosomes in (f) A. petricola. Scale bars: $10 \mu \mathrm{m}$. 
A. grandidentata, A. maculata and A. petricola, and from one to eight in $A$. excelsa (Tab. 1, Fig. 3 ). Despite the polymorphism in the number of active NORs and the number of nucleoli found in the most of the tested species, the proportions between the two characters are similar in many cases. So, for example, A. dichotoma presents a metaphases with three and four active NORs in minor and major proportion, respectively (Tab. 1), their corresponding interphase nuclei showed three and four nucleoli respectively (Fig. 3), which could indicate a competitive relationship between NOR areas during the transcription process, resulting nucleoli formation only in those active sites. Thus, the number of observed nucleoli at interphase could help to predict the number of active NORs that would be expected in any species from Aloe. Similarly, in most cases, the maximum number of active NORs coincides with the maximum number of nucleoli, helping to predict the most active areas of expected NORs in Aloe species, only counting nucleoli in interphase nuclei.

The polymorphism showed by Aloe's species respect to the NOR's activity could reflect some competition between homologous and non-homologous chromosomes, as could be seen in $A$. grandidentata, where the formation of three nucleoli and only three NOR active zones, contrast with the eight ones that might be expected from the number of secondary constrictions and the developed NORs observed in Figure $1 \mathrm{~b}$. Competition for the formation of the nucleoli and transcriptional activation of DNA is common for hybrid taxa and/or polyploids, as in hexaploid Avena bizantina C. Koch $(6 \mathrm{x}=42)$, where only three chromosome pairs showed nucleolar organization regions despite the twelve expected sites due its ploidy level, therefore, the inactivation of the nucleolus is suggested (Linares et al. 1992). Similarly, amphyplasty in hybrids between Secale cereale cv Petkus and Triticum turgidum cv Dwarf Andujar have been observed, where the first NOR's expression is suppressed by the presence of the genome of the latter, as expected in natural Triticum allopolyploids (Lacadena et al. 1984).

From the above ideas, it would be desirable to evaluate polyploid species of Aloe and nearby groups in order to determine whether there is a real dominance in the NOR expression or if it is simply a plastic character as noted in other groups (Hasterok and Maluszynska 2000). Nucleolar dominance is a common phenomenon in plant and animal hybrids: the genes of one parent are expressed, while whose from the other parent remain silent by epigenetic factors such as methylation, modification in the structure of histones and reorganization of nucleosomes (Santoro 2005).

The hybrid origin indicated by Sato (1937), Reynolds (1966) and Brandham (1971) for Aloe speciation, could influence the high competition in terms of NOR's expression. This phenomenon is also supported by Adams et al. (2000), who indicate variability in the distribution, number and size of rDNA (18S- 5, 8S-26S) loci between species of Aloe, which could be explained by hybridization and speciation events occurred in Aloe.

\section{NORs and their systematic value} in Aloe

The location and expression of NORs as a phylogenetically and taxonomically informative value have been proven in several groups of reptiles, amphibians and fishes (Odierma et al. 2001). Within the angiosperms, the location and expression of NORs in species of the genus Capsicum allowed to establish evolutionary relationships (Moscone et al. 1995). In Aloe, NORs may have an informative systematic importance, grouping species in terms of NOR's location (Sánchez 2010), but not under the criterion of their expression, because as previously noted, the NOR's activity is polymorphic, not only within an individual, but between cells from the same root. The activation of NOR areas and their respective number of associated nucleoli seems to matter for each individual cell in this group but don't have a genetic consequence, since it seems to be a characteristic of each species or number of individuals, with the exception of Aloe petricola, species on which both patterns were consistent.

Furthermore, a general feature in Aloe seems to be the tendency to the nucleolar fusion, occurring in the largest proportion of interphase nuclei, developing only nucleoli in species of Pachydendron's section, two nucleoli in $A$. littoralis, A. grandidentata, and A. maculata, and three nucleoli in $A$. dichotoma and $A$. immaculata. Thus, Santoro (2005) established that as long as the cell cycle progresses, small nucleoli formed adjacent to the active NORs could merge into larger nucleoli. This kind of nucleolar fusion has also been reported in hybrids between Secale cereale cv Petkus and Triticum turgidum cv Enano de Andujar, and it has been attributed to the proximity of the forming nucleoli (Lacadena et al. 1984). 


\section{Conclusions}

Development of active NORs and number of nucleoli in interphase nuclei are polymorphic between Aloe's tested species, with the exception of Aloe petricola where AgNOR active subtelomeric regions were always developed on the long arm of one of the $\mathrm{L}_{2}$ chromosomes, and on the $\mathrm{L}_{4}$ pair, coinciding with the maximum number of interphase nucleoli (three). Active NORs were revealed on the secondary constrictions in the long arms of the large chromosomes or on the short arms of small chromosomes, coinciding with the CMA+ DAPI- adjacent caps at both ends of the secondary constriction of all tested species (Sánchez 2010). In most cases, NOR active zones were observed on the $\mathrm{L}_{2}$ and $\mathrm{L}_{4}$ pairs, excluding Aloe dichotoma and $A$. maculata, on which they were revealed in the short arm of the $\mathrm{S}_{2}$ pair, $\mathrm{S} 1$ second constriction, respectively. Amphyplasty is a common feature, both referring to the activation zones of the NOR organizer and during the formation of nucleoli in the interphase nucleus, a phenomenon that can be associated with the hybrid origin of Aloe. In all cases, the maximum number of nucleoli corresponds to the greatest number of active NORs observed for each species.

\section{Acknowledgements}

The authors are thankful to the Fondo Nacional de Ciencia Tecnología e Innovación (FONACIT, Venezuela) by encouragement and help, and the Instituto Multidisciplinario de Biología Vegetal (IMBIV, Argentina) by supporting and facilities.

\section{References}

Adams S, Leitch L, Bennett M, Chase M \& Leitch A (2000) Ribosomal DNA evolution and phylogeny in Aloe (Asphodelaceae). American Journal of Botany 87: $1578-1583$

Berg C \& Greilhuber J (1992) Cold-sensitve chromosome regions and their relation to constitutive heterochromatin in Cestrum parqui (Solanaceae). Genome 35: 921-930.

Bourgourd S \& Parker J (1976) Nucleolar-organizer polymorphism in natural populations of Allium schoenoprasum. Chromosoma 56: 301-307.

Brandham PE \& Doherty MJ (1998) Genome size variation in the Aloaceae, an angiosperm family displaying karyotypic orthoselection. Annales of Botany 82 (Supplement A): 67-73.

Brandham PE (1971) The chromosomes of the Liliaceae: II* Polyploidy and karyotype variation in the Aloineae. Kew Bulletin 25: 341-348.
Ebert I, Greilhuber J \& Speta F (1996) Chromosome banding and genome size differentiation in Prospero (Hyacinthaceae). Plant Systematic and Evolution 203: 143-177.

Goodpasture C \& Bloom SE (1975) Visualization of nucleolar organizer regions in mammalia chromosomes using silver staining. Chromosoma (Berl.) 53: 37-50.

Hasterok R \& Maluszynska J (2000) Nucleolar dominance does not occur in root tip cells of allotetraploid Brassica species. Genome 43: 574579.

Imery J \& Caldera T (2002) Estudio cromosómico comparativo en cinco especies de Aloe (Aloaceae). Acta Botánica Venezuélica 25: 47-66.

Imery J (2007) Caracterización genética de parentales e híbridos diploides [VS] y triploides [VVS] entre Aloe vera L. Burm. F. [2V, 4V] y A. saponaria Haw. [2S] (Aloaceae). Tesis Doctoral. Universidad Central de Venezuela, Caracas. 147p.

Kodama Y, Yoshida M \& Sasaki M (1980) An improved silver staining technique for nucloeolus organizer regions by using nylon cloth. International Journal of Human Genetics 25: 229-233.

Lacadena J, Cermeño M, Orellana J \& Santos J (1984) Evidence for wheat-rye nucleolar competition (amphiplasty) in triticale by silver-stainig procedure. Theoretical and Applied Genetics 67: 203-213.

Levan A, Fredg K \& Sandberg A (1964) Nomenclature for centromeric position on chromosomes. Hereditas 52: 201-220.

Lim K, Wennekes J, Jong H, Jacobsen E \& Van Tuyl J (2001) Karyotype analysis of Lilium longiflorum and Lilium rubellum by chromosome banding and fluorescence in situ hybridization. Genome 44: 911-918.

Linares C, Vega C, Ferrer E \& Fominaya A (1992) Identification of C-banded chromosomes in meiosis and the analysis of nucleolar activity in Avena byzantina C. Koch cv 'Kanota'. Theoretical and Applied Genetics 83: 650-654.

Matos A, Molina J \& Acosta D (1998) Localización de NORs en cromosomas de Aloe vera L. (Aloaceae). Acta Botánica Venezuélica 21: 1-9.

Modin M, Santos-Serejo J \& Aguiar-Perecin M (2007) Karyotype characterization of Crotolaria juncea (L.) by chromosome banding and physical mapping of 18S-5.8S-26S and 5S rRNA gene sites. Genetics and Molecular Biology 30: 65-72.

Moscone E, Loidl J, Ehrendorfer F \& Hunziker A (1995) Analysis of active nucleolus organizing regions in Capsicum (Solanaceae) by silver staining. American Journal of Botany 82: 276-287.

Odierma G, Vences M, Aprea G, Lötters S \& Andreone F (2001) Chromosome data for Malagasy poison frogs (Amphibia: Ranidae: Mantella) and their 
bearing on taxonomy and phylogeny. Zoological Science 18: 505-514.

Reynolds GW (1966) The Aloes of tropical Africa and Madagascar. The Trustees/The Aloe Book Fund, PMbabane. 537p.

Reynolds T (2004) Aloes: the genus Aloe. Medicinal and aromatics plants - industrial profiles. Vol. 25. CRC Press LLC, Boca Raton. 408p.

Sánchez Y, Imery J \& Raymúndez M (2007) Estandarización del protocolo AgNORs en Aloe petricola Pole Evans (Aloaceae). Revista de la Facultad de Agronomía 24 (Suppl. 1): 1-6.

Sánchez Y (2010) Contribución al conocimiento citotaxonómico en el género Aloe L. (Aloaceae) basado en patrones de bandeo cromosómico C, AgNOR, DAPI Y CMA. Tesis Doctoral. Universidad Central de Venezuela, Caracas. 500p.

Santoro R (2005) The silence of the ribosomal RNA genes. Cellular and Molecular Life Science 62: 2067-2079.
Sato D (1937) Karyotype alteration and phylogeny. I. Analysis of Karyotypes in Aloineae with special reference to the SAT-chromosomes. Cytologia, Fujii Jubilee 3: 80-95.

Schwarzacher T, Ambros P \& Schweizer D (1980) Application of Giemsa banding to orchid karyotype analysis. Plant Systematic and Evolution 134: 293-297.

Sharma AK \& Mallick R (1965) Interrelationships and evolution of the tribe Aloineae as reflected in its cytology. Journal Genetics 59: 110-137.

The Plant List (2013) The plant list. Version 1.1. Avaiable at <http://www.theplantlist.org/> Access on 15 July 2017.

Vieira R, Queiroz A \& Viegas W (1990) Visualization of nuclear regions in nucleoli of interphase plants cells. Cytologia 55: 339-347.

Vij SP, Sharma M \& Toor IS (1980) Cytogenetical investigation in some garden ornamentals II. The genus Aloe L. Cytología 45: 515-532. 